\title{
Radikalisme Agama Legitimasi Tafsir Kekerasan di Ruang Publik
}

\author{
Musa Rumbaru, Hasse J. \\ STAIN Al Fatah Jayapura, Universitas Muhammadiyah Yogyakarta \\ stainalfatah.jayapura@yahoo.com, hasse@umy.ac.id
}

\begin{abstract}
Religious radicalism shows a high intensity over the last decade in Indonesia. This religious radicalism subsequently brings a massive impact when it is admitted by the action of choosing violence as the only way. In this article, we put forward our arguments: first, the point of intersection between violence and religion; second, radicalism used as a method to respond to various issues such as injustice, and so on. Third, regarding alternative methods that can be done in order to minimize radical action and understanding in Indonesia. This paper confirms three main points. First, the teaching of religion, especially Islam basically contains the peace teachings and safety; therefore, one was very antiviolence and radical actions. Second, radical action can be a method to hear our voices in response to various injustices that occur in a few places in the world. Third, understand the narrowly religious texts have an impact on building understanding and narrow action anyway.
\end{abstract}

\begin{abstract}
Abstrak
Radikalisme agama menunjukkan intensitas yang tinggi dalam satu dekade terakhir ini di Indonesia. Paham radikal ini kemudian berdampak luas ketika diikui oleh aksi yang memilih kekerasan sebagai metodenya. Tulisan ini dititikberatkan pada, pertama, titik persinggungan antara kekerasan dan agama; kedua, radikalisme dijadikan metode untuk merespons berbagai persoalan seperti ketidak-adilan, dan sebagainya; ketiga, menyangkut alternatif metode yang dapat dilakukan dalam rangka meminimalisir tindakan dan paham radikal di Indonesia. Tulisan ini menegaskan tiga hal pokok. Pertama, ajaran agama khususnya Islam pada dasarnya berisi tentang ajaran kedaiaman dan keselamatan sehingga ia sangat anti terhadap kekerasan dan aksi radikal. Kedua, aksi radikal menjadi metode menyuarakan aspirasi sebagai respons terhadap berbagai ketidak-adilan yang terjadi di beberapa tempat di dunia. Ketiga, memahami teks agama secara sempit berdampak pada bangunan pemahaman dan aksi yang sempit pula.
\end{abstract}

Keywords radicalism, religion, violence, tafsir 


\section{A. Pendahuluan}

Sejumlah aksi radikal di Indonesia dalam beberapa dekade terakhir menunjukkan intensitas yang mengkhawatirkan. Berbagai aksi radikal dan kekerasan menjadi perbincangan hangat di tengah upaya-upaya serius membangun tatanan kehidupan masyarakat yang lebih harmonis. Kelompok-kelompok radikal beraneka jubah memperkenalkan masingmasing back ground-nya, mulai dari yang berwajah etnis hingga agama. Dari sejumlah peristiwa, kolompok radikal agamalah yang memegang dominasi kekerasan tersebut. Peristiwa konflik horizontal yang berlatar belakang agama misalnya dapat disaksikan di tengah upaya membentuk tatanan kehidupan sosial masyarakat yang menghargai perbedaan. Misalnya konflik Sampang, penyerangan terhadap rumah Pendeta di Yogyakarta, pelarangan menggelar acara takbiran di Papua, dan lain-lain menjadi pelengkap pasang-surutnya tensi kehidupan (beragama) di Indonasia. Menguatnya gerakan radikal tersebut muncul sejak pertengahan 90-an dengan beragam bentuk dan pola yang relatif sama, yaitu memaksakan kehendak kepada orang/kelompok lain serta menganggap diri dan kelompoknya yang paling baik.

Berdasarkan data yang dipublikasikan oleh The Wahid Institute (sekarang Wahid Foundation) pada tahun 2014, sebanyak 245 peristiwa pelanggaran dan intoleransi beragama. ${ }^{1} \mathrm{Di}$ antara kekarasan tersebut, setidaknya terdapat 106 peristiwa yang melibatkan negara dan 139 peristiwa oleh non-negara. ${ }^{2}$ Pada Agustus 2016 lalu, Wahid Foundation kembali mempublikasikan hasil survei yang dilakukan bekerjasama dengan LSI, tentang intoleransi dan radikalisme yang dilakukan pada 34 propinsi. Hasil survei menunjukkan bahwa potensi intoleransi dan radikalisme di Indonesia sangat terbuka. Dari 1520 responden (beragama Islam berumur 17 tahun ke atas), sebanyak 59,9\% dari mereka menyatakan memiliki kelompok yang dibenci. Terdapat $7,7 \%$ responden

${ }^{1}$ Muhammad Takbir, Etika Religious Emmanuel Levinas dalam Perspektif Filsafat Agama dan Relevansinya dengan Pluralitas di Indonesia, "Tesis" (Yogyakarta: Program Pascasarjana Ilmu Filsafat UGM, 2015), h. 5.

${ }^{2}$ Beberapa kasus serupa dapat dilihat dalam Hafidz Hasyim, Klaim Kebenaran Agama dalam Bingkai Psikologi Agama dan Analitika Bahasa (Yogyakarta: Pustaka Pelajar-STAIN Jember Press, 2013), h. 31-45. Dari beberapa kasus tersebut terlihat bahwa sentimen agama sangat kuat dan dapat dijadikan alat untuk menyerang kelompok (agama) lain, seperti perusakan tempat ibadah, pelarangan pendirian tempat ibadah, penutupan akses jalan, dan lain-lain. 
yang bersedia melakukan tindakan radikal bila ada kesempatan dan sebanyak $0,4 \%$ justru pernah melakukan tindakan radikal. Meskipun hanya sebesar $7,7 \%$ yang menyatakan bersedia melakukan aksi, namun persentase tersebut tetap mengkhawatirkan. Sebab, 7,7 \% jika proyeksinya dari 150 juta umat Islam Indonesia berarti terdapat sekitar 11 juta orang yang bersedia bertindak radikal. Jumlah 11 juta umat Islam ini hampir sama dengan penduduk Jakarta dan Bali.

Kondisi di atas memperlihatkan bahwa realitas kemayoritas Muslim di Indonesia juga diikuti oleh tingginya potensi aksi-aksi radikal dilakukan oleh pemeluk Islam. Meskipun sesungguhnya tidak ada ajaran agama yang menyerukan aksi radikal sebagai metodenya, namun dalam praktiknya jamak ditemukan. Agama sebagaimana pendapat beberapa sarjana, merupakan sumber nilai dan insipirasi umatnya melakukan kebaikan, seakan-akan hilang fungsinya ketika pada beberapa kasus justru menunjukkan hal sebaliknya. Agama sering ditempatkan pada posisi justifikasi tindakan kekerasan. Padahal, dalam doktrin agama, kekerasan tidak dibolehkan karena berlawanan dengan esensi agama itu sendiri yang pada prinsipnya sangat mencintai keharmonisan, perdamaian, dan kemaslahatan (agama sebagai rahmat). Agama mengajarkan keteraturan, keseimbangan, dan paling penting adalah menjunjung tinggi perbedaan. Agama memiliki fungsi kultural dan sturktural. ${ }^{3}$ Fungsi kulturalnya terletak pada adanya penyakralan nilai dan norma yang dianut dan hidup dalam masyarakat. Agama memberikan landasan non-empiris dan menyakralkan nilai dan norma tersebut. Nilai tersebut pun merupakan pengendali ketertiban dalam masyarakat. Singkatnya, agama mampu mendorong dan bahkan memaksa pemeluknya menaati nilai dan norma demi kepentingan masyarakat. Adapun fungsi struktural agama artinya ia merupakan struktur masyarakat yang memiliki sifat integratif melalui nilai dan norma tadi. Oleh karena itu, agama khsusunya Islam memiliki mekanisme dan metode mengajak orang yang berbeda. Mengajak orang lain di luar Islam untuk masuk Islam pun dilakukan dengan metode santun dan lemah lembut. Artinya, Islam sangat sensitif menyangkut isu perbedaan, dan sadar atas realitas adanya kelompok di luar Islam itu sendiri.

Dalam al-Qur'an diajarkan metode mengajak orang lain untuk menjadi bagian dari Islam. Metode tersebut harus dilakukan dengan cara ${ }^{3}$ Imam Sukardi, dkk, Pilar Islam bagi Pluralisme Modern (Solo: Tiga Serangkai,
2003), h. 36-37 
nir-kekerasan. Hal ini dapat ditemukan, misalnya, dalam QS Ali Imran 159 dan An Nahl 125. Kedua ayat tersebut secara singkat dan sederhana dapat dipahami sebagai penjelasan mengenai cara yang sebaiknya dilakukan dalam melakukan dakwah. "Sekiranya mengajak orang lain dengan berhati kasar, maka mereka pun akan menajuh", demikian sedikit makna yang dapat ditangkap dari ayat tersebut. Oleh karena itu, perlu ajakan yang santun dan penuh dengan hikmah, bukan dengan cara kekerasan. Secara logika sederhana, jika mengajak siapa saja dengan cara yang kurang baik, tentu saja akan menciptakan kesan yang kurang baik pula. Demikian pula, jika ajakan dilakukan dengan cara-cara yang kurang santun, tentunya juga akan melahirkan pengikut yang nantinya memiliki sikap seperti itu.

Pada satu sisi, agama yang sejatinya menjadi tata nilai bagi pemeluknya untuk menghormati dan menghargai sesama manusia justru pada sisi lain menjadi destrukrif dan tidak menghargai nilai-nilai kemanusiaan. Hal ini, bagi Sigmund Frued dan Karl Marx menganggap agama sebaagi sumber masalah dalam masyarakat, bahkan agama merupakan penyakit saraf. ${ }^{4}$ Agama seringkali dan bahkan mejadi landasan ideologis dari pelaku kekerasan. Pemberian landasan ini bukan hanya meringankan atau memberi alibi tanggung jawab pribadi, tetapi semakin meneguhkan tekad, mempertajam permusuhan dan memistiskan motif pertentangan menjadi membela iman dan kebenaran, demi tuhan itu sendiri. ${ }^{5}$ Ini direproduksi secara terus-menerus hingga menjadi visi yang "seolah-olah" memperjuangkan kebenaran dan kemanusiaan.

Mengacu pada latarbelakang di atas, tulisan ini akan menguraikan lebih jauh mengenai kekeliruan penganut agama dalam memperlakukan agamanya sehingga aksinya cenderung memaksa orang lain mengikuti kehendaknya. Dalam tulisan ini juga memuat mengenai tawaran pemikiran mengenai cara mereduksi paham dan aksi radikal yang mengatasnamakan agama (Islam). Sebelum sampai pada analisis tersebut, terlebih dahulu penulis menguraikan secara sekilas hubungan antara agama dan kekerasan dalam konteks normatifnya.

${ }^{4}$ Daniel L Pals, Seven Theories of Religion. Terj. Inyiak Ridwan Muzir (Yogyakarta: IRCiSod, 2012), h. 115.

${ }_{5}$ Haryatmoko, Etika Politik dan Kekuasaan (Jakarta: Kompas, 2003), h. 63. 


\section{B. Relasi antara Agama dan Kekerasan}

Jika membaca secara teliti peristiwa-peristiwa besar kekerasan yang disebabkan oleh agama, ditemukan paling tidak ada tiga peran yang menyebabkan kerentanan agama terhadap kekerasan. ${ }^{6}$ Pertama, adanya penafsiran agama dalam hubungannya dengan relasi sosial. Tafsiran ini selanjutnya menjadi dasar ideologis dari pemeluk agama dalam ruang sosial. Yakni, tatanan sosial ditafsirkan sedemikian sehingga berdasarkan kerangka religius tertentu. Tatanan masyarakat direpresentasikan sebagai kehendak Tuhan berdasakan hasil tafsirannya sendiri terhadap teks suci. Diversitas realitas diunifikasi dan disimplifikasi menjadi suatu realitas yang seragam. Identitas-identitas subjek yang unik akhirnya hilang dalam suatu kerangka pemahaman (tafsir) yang "sempit". Sebab, realitas yang kompleks dan jamak diarahkan pada kehendak kelompok tertentu. Di sinilah, keberadaan orang/kelompok lain mulai dinafikan. Bahkan, jika umat beragama tidak mau mengubah pemahaman yang diyakini sebagai "kebenaran mutlak", maka agama mandul, nyaris tak bermakna. ${ }^{7}$

Selain itu, tafsiran ini juga memiliki kecenderungan menyembunyikan kepentingan pribadi dan kelompok tertentu. Penyembunyian ini menurut Haryatmoko, terkait dengan peran ideologis agama, dalam arti sebagai faktor integrasi dan pembenaran dominasi. Apa yang ditafsirkan dan mendapat pembenaran dari agama adalah hubungan kekuasaan karena setiap tindakan dan setiap kekuasaan selalu mencari legitimasi. ${ }^{8}$ Kekuasaan menuntut lebih dari keyakinan yang dimiliki. Keberagaman jenis ini, menurut Raza Wittemena sebagai keberagamaan "anak kecil" yang jauh dari kedewasaan. Anak kecil masih sangat egoistik dan belum dapat mempertimbangkan ruang sosial di mana ia hidup. Ia masih perlu diarahkan, dinasehati dan ditunjukkan jalan yang tepat. Tanpa ia akan mencelakai orang lain dan bahkan dirinya sendiri.

Kedua, terbentuknya identitas kolektif keagamaan yang terintegrasi dengan identitas etnik. Ini dapat dilihat misalnya sada pengidentifikasian masyarakat Aceh sebagai masyarakat Muslim dan

${ }^{6}$ Band. Ibid, . h. 64.

7 Zuly Qodir, Radikalisme Agama di Indonesia (Yogyakarta: Pustaka Pelajar, 2014), h. 55.

${ }^{8}$ Haryatmoko, Etika Politik dan Kekuasaan (Jakarta: Kompas, 2003), h. 65. 
Batak adalah Kristen, Bugis Islam ${ }^{9}$ dan Toraja Kristen, Nusa Tenggara Barat Muslim dan Nusa Tenggara Timur Kristen, dan lain-lain. Pengidentifikasian ini membawa pada sikap yang fanatik, karena pada saat yang sama memiliki dua alasan sekaligus. Rawannya, masyarakat yang mengidentifikasi diri dalam salah satu kelompok ini sulit menerima keberdaan orang lain. Orang lain (di luar kelompoknya) selalu dipandang sebagai yang lain (the others). Bahkan, mereka telah melabelkan predikat tertentu orang lain berdasarkan pikirannya sendiri, bukan sebagaimana yang dipikirkan oleh orang (lain) itu sendiri. Pada akhirnya, yang terjadi adalah stigmatisasi dan stereotiping. Orang lain dibentuk dan citrakan sebagai masyarakat yang lebih rendah, kumuh, kurang beradab, kasar, dan lain-lain bahkan dianggap tidak berperadaban. Ini terjadi tidak pada satu pihak saja, tetapi juga pada pihak lainnya. Pada tingkat yang lebih ekstrim, kelompok etnis dan agama yang berbeda dengannya dipandang sebagai "setengah manusia". Akibatnya, ketika mereka membunuh salah satu dari mereka pun tidak diangggap sebagai suatu beban atau kesalahan, tetapi sebagai sesuatu yang biasa-biasa saja bahkn dianggap sebagai bagian dari 'ibadah'.

Ketiga, semakin kuatnya legitimasi moral dalam tatanan sosial. Berbeda dengan yang pertama, yang melihat tatanan sosial dalam kerangka tafsir teologis, pada bagian ini agama dilegitimasi dan direpresentasikan dalam suatu nilai yang sudah penuh. Mereka merasa tidak memerlukan lagi perangkat nilai lain yang datang dari luar, seperti nilai egaliter, kemanusiaan, keadilan, dan lain lain. Nilai-nilai seperti ini dipandangnya sebagai sesuatu yang baru, sehingga ditolak dan dipandang sebagai produk Barat yang kafir. Islam dipahami, bahkan, sebagai agama yang tidak memiliki keterkaitan dengan tradisi lain. Barat sering dipertentangkan dengan Islam. Pada kasus Islam dan demokrasi misalnya, ada setidaknya tiga kelompok besar yang selalu mengitari isu ini. Ada kelompok yang menamakan diri rejeksionis yang dengan terbuka menolak demokrasi dengan alasan ia adalah produk Barat. Ada pula yang menggolongkan diri sebagai kelompok menerima demokrasi. Juga ada kelompok apologetis yang melihat bahwa demokrasi juga di dalamnya terdaapt nilai-nilai Islam, artinya sangat islami. Sebab, baginya Islam

${ }^{9}$ Hasse J, Konformitas Islam dan Adat: Potret Fanatisme Keagamaan di Kalangan Muslim Bugis, Jurnal Jabal Hikmah, Vol. 3 No. 2 (Jayapura: STAIN Al Fatah, 2014), h. 199. 
sangat menjunjung tinggi nilai-nilai persamaan, keadilan, dan lain-lain sebagaimana demokrasi. Kelompok terakhir adalah kelompok yang selalu memposisikan diri pada titik aman, tidak memihak secara jelas pada dua kelompok tadi.

Pelabelan "Barat kafir" pada dasarnya sudah mengundang permasalahan. Mengeneralisasi semua orang Barat kafir adalah sikap yang irrasional, karena di sana juga terdapat orang-orang yang agamanya sama dengannya. Selain itu, sikap defence-nya ini membuatnya semakin kebal terhadap sesuatu yang asing dari padanya. Mereka ini mengidentifikasi dirinya sebagai yang lain, yang berbeda. Mereka membuat simbol-simbol untuk mengidentikasi kelompoknya. Melalui simbol ini, mereka memperlawangkan dirinya dengan mereka yang memiliki simbol berbeda atau bahkan yang tidak ada dalam asosisasi simbolik kelompoknya. Mereka pun mngkonstruksi orang yang berbeda tersebut sebagai orang yang berada di luar jalur kebenaran (kafir). Sebagai akibatnya, orang lain berbeda tersebut tidak begitu berarti baginya, bahkan pada kondisi tertentu mereka dapat saja menghancurkannya dengan dalih teologis.

Sikap untuk menghancurkan yang lain seolah-olah merupakan keinginan Tuhan itu sendiri. Nama Tuhan pada akhirnya menjadi alasan kuat untuk menghacurkan yang lain. Dalam pandangannya, mereka menganggap bahwa bukan mereka yang bertindak tetapi Tuhan. ${ }^{10}$ Adapun tindakannya adalah berdasarkan perintah Tuhan, seolah-oleh Tuhan sendiri yang menginginkan hal tersebut. Mereka sendiri seperti tidak memiliki andil dalam peristiwa kekerasan yang dilakukannya. Dengan kata lain, mereka "cuci tangan" atas nama Tuhan. Sikap seperti ini muncul bukan tanpa sebab. Ia mengemuka akibat akumulasi pemahaman yang dangkal dan interpretasi yang sempit terhadap teks agama. Teks ditafsirkan sangat tekstual, tanpa memperhatikan konteks sosial masyarakat yang semakin dinamis. Pada kondisi ini, teks pun kemudian menjadi senjata yang dapat digunakan untuk menyerang kelompok di luar dirinya.

Selain tiga hal di atas, aktor yang turut mendukung terjadinya kekerasan adalah negara. Sekiranya ada "tekanan dari negara terhadap kelompok-kelompok ini maka kekerasan dapat terhindarkan". Fungsi

${ }^{10}$ Muhammad Takbir, Etika Religious Emmanuel Levinas dalam Perspektif Filsafat Agama dan Relevansinya dengan Pluralitas di Indonesia, "Tesis" (Yogyakarta: Program Pascasarjana Ilmu Filsafat UGM, 2015), h. 5. 
negara sebagai pemberi rasa amantidak tampak. Justru ia seperti melakukan pembiaran terhadap tindakan-tindakan anarkis. Bahkan dalam banyak kasus, seperti konflik Ambon dan Poso, negara dianggap terlibat di dalamnya. Kekerasan atas nama agama yang terjadi secara laten di kedua tempat ini tidak dapat dikatakan bahwa negara tidak terlibat sama sekali. Bagaimana kita dapat mengatakan bahwa negara tidak terlibat jika ini berlangsung secara terus-menerus hingga kini dan tidak ada solusi yang menyeluruh? Bagaimana kiranya menjelaskan konflik Ambon yang pelakunya menurut keterangan masyarakat setempat adalah institusi negara- TNI berdiri dipihak muslim dan Polri berdiri di pihak Kristen? Bukankan negara merupakan pemegang kendali dan kekuasaan serta kekuatan yang paling tinggi di negeri ini?

Menurut penjelasan Hug Heclo, ${ }^{11}$ dalam esainya, Religion and Public Policy, bahwa terdapat interaksi antara agama dan kebijakan publik yang paling tidak dapat dilihat dalam tiga level. Pertama, level institusi dimana perhatiannya difokuskan pada cara mengorganisasikan struktur agama dan kebijakan publik terkait dalam masyarakat, baik secara berbeda maupun bersama. Kedua, tindakan, yakni ide tentang keagamaan selalu diorganisir melalui publik. Ketiga, adalah filsafat dimana ide-ide keagamaan yang oleh pembuat kebijakan di-capture dalam suatu kehidupan publik masyarakat. Pada konteks saat ini, agama dijadikan sebagai legitimasi kebijakan dalam ruang publik. Agama yang nilainya transendental menjadi profan, dan bahkan meaningless (tanpa makna).

Dalam banyak kasus, beberapa daerah mengkampanyekan penerapan syariat Islam yang didesain melalui pembuatan perda syariah. Bahkan, di Nanggroe Aceh Darussalam hukum Islam resmi diberlakukan untuk mengatur dinamika kehidupan bermasyarakat di sana. Realitas ini memantik keinginan perlakuan yang sama di tempat lain. Di Papua misalnya, terdapat keinginan untuk juga membuat perda Injili. Hal ini tidak berdiri sendiri, karena merupakan keberlanjutan perda syariah di beberapa tempat di mana Muslim menjadi penduduk mayoritas seperti di Aceh. Sesungguhnya, hal ini sangat baik dalam rangka menunjukkan semangat keberagamaan yang kental sebagai jati diri bangsa Indonesia yang dikenal religius. Akan tetapi, pada praktiknya tidak jarang justru dari sinilah awal kemunculan ketegangan yang melibatkan pemeluk agamaagama.

${ }^{11}$ Hug Heclo, 2001, "Religion and Public Policy: An introduction", Journal of Policy History, Vol. 13. Issue 1. 
Di berbagai belahan dunia, realitas 'meniru' dari satu peristiwa kemudian mempraktikkannya di tempat lain meskipun sering tidak sesuai konteksnya sangat masif. Budaya meniru ini, dalam kasus Indonesia misalnya, menjadi salah satu sikap 'membalas' perlakuan yang dialamatkan kepada satu kelompok agama tertentu. Kasus perda Injili di Papua merupakan salah satu contoh riil adanya keinginan tersebut yang tidak bisa dilepaskan dari berbagai kebijakan di daerah-daerah mayoritas Muslim menerapkan syariat Islam yang salah satunya mewujud dalam bentuk peraturan daerah. Bagi penulis, ini merupakan bibit radikalisme yang jika tidak dikelola dengan baik akan menemukan momennya pada waktu tertentu dan akan membawa dampak yang justru merugikan banyak pihak.

Dari penjelasan di atas maka semakin jelaslah mudus-modus operandi kekerasan atas nama agama. Agama yang sejatinya diinternalisasi dan direfleksikan menjadi nilai utama kehidupan pada akhir menjadi kehilangan makna dan fungsinya. Agama tidak lagi mengajarkan kasih sayang, tetapi justru menawarkan kekejaman dan kedengkian. Fungsi agama pun beralih menjadi fungsi pragmatis dan hanya digunakan oleh sekelompok orang yang memiliki obsesi berlebihan dalam mencapai hasratnya. ${ }^{12}$ Fungsi agama sebagai rahmat (Islam) tidak lagi tercermin dan terefleksikan dalam tutur dan tindakan, ia justru diseret mengikuti kepentingan yang bersifat pragmatis-oportunis. Hukum agama tidak lagi memihak pada kebenaran yang mengedepankan penghargaan terhadap harkat dan martabat kemanusiaan, menjunjung tinggi keadilan, kesetaraan dan spirit positif lainnya, hukum bahkan justru memihak kepada siapa yang memiliki kekuatan yang digunakan untuk menindas yang lemah, minoritas, dan kelompok-kelompok termarginalkan lainnya. Baik agama maupun hukum muncul dengan wajah menyeramkan, yang jauh dari konteks dasarnya yang berisi misi kedamaian dan anti terhadap kekerasan.

\section{Radikalisme sebagai Sebuah Pilihan Metode}

Radikalisme, khususnya radikalisme Islam muncul sebagai respons terhadap kondisi memperihatinkan yang dialami dan dihadapi umat. Persoalan ketimpangan, ketidakadilan, dan diskriminasi terjadi di mana-mana yang memantik aksi sekelompok orang melakukan berbagai

${ }^{12}$ Mun'in A Sirry, Membendung Militansi Agama: Iman dan Politik dalam Masyarakat Modern (Jakarta: Penerbit Erlangga, 2003), h. 41. 
upaya dalam rangka melakukan perlawanan terhadap kondisi-kondisi tersebut. Umumnya, pilihan tindakan yang diambil adalah jalur kekerasan karena jalur lain dianggap tidak 'mempan' lagi. Di dunia Islam, misalnya di Timur Tengah, radikalisme Islam muncul sebagai perlawanan kontraproduktif terhadap perlakuan tidak adil atau penyumbatan aspirasi politik oleh rezim otoriter. ${ }^{13}$ Bagi John L Esposito, hal ini dapat dibaca sebagai bentuk kebangkitan dunia Islam dalam rangka pencarian identitas, otentisitas, dan komunitas di tengah himpitan perlakuan tidak adil yang dialami selama ini.

Bagi Mun'in A Sirry ${ }^{14}$ menguatnya radikalisme Islam merupakan fenomena modern. Mereka yang tergabung dalam kelompok ini berasal dari intelektual perkotaan, artinya berasal dari kalangan masyarakat moderen (modernis). Bagi mereka, apa yang dipilih merupakan cara untuk melawan unfairness yang dapat mewujud dalam bentuk modernisasi termasuk produk-produknya. Dalam konteks Indonesia, fenomena radikalisme bahkan fundamentalisme juga marak dan terus mendapat respons dari penentangnya. Radikalisme Islam direspons oleh moderasi Islam yang mengusung ide keterbukaan dan kesetaraan. Sementara itu, fundamentalisme dilawam dengan mempromosikan demokrasi yang dianggap telah menemukan tempatnya di Indonesia. Indonesia terkait dengan hal demokrasi dinilai berhasil karena kedaulatan telah berada di tangan rakyat.

Tindakan radikal dipicu oleh, salah satunya adalah, kekurangpuasan terhadap kondisi yang sedang terjadi. Ada sikap yang tidak bisa lagi dibendung karena telah terjadi dan terus berulang tanpa diiringi oleh upaya nyata (oleh negara) untuk menyelesaikannya. Hal ini pun kemudian direspons dengan berbagai bentuk tindakan (kekerasan) yang diikuti oleh pelibatan teks kitab suci (Al Qur'an) sebagai alat pengesah tindakan. Jika dirunut lebih jauh ke belakang, pemahaman akibat penafiran yang sempit terhadap teks kitab suci menjadi pemicu utama munculnya paham radikal. Paham radikal sesungguhnya menjadi fenomena biasa. Sebab, dalam tradisi agama mana pun di luar Islam, fenomena ini dapat ditemukan dengan berbagai varian dan dinamikanya. Dalam tradisi ke-Kristen-an misalnya, paham ortodoksi yang mengarah pada paham keras (baca:

${ }^{13}$ Mun'in A Sirry, Membendung Militansi Agama: Iman dan Politik dalam Masyarakat Modern (Jakarta: Penerbit Erlangga, 2003), h. 36.

14 Mun'in A Sirry, Membendung Militansi Agama: Iman dan Politik dalam Masyarakat Modern (Jakarta: Penerbit Erlangga, 2003), h. 37. 
fundamentalisme) juga berkembang dan terus mengikuti perjalanan Kristen. Paham radikal menjadi luar biasa ketika dilanjutkan dengan tindakan radikal yang menggunakan kekerasan dan pemaksaan sebagai metodenya.

Pemahaman yang sempit terhadap Islam yang lahir dari interpretasi yang bersifat parsial terhadap teks membentuk pola pikir yang sangat kaku. Bahkan, apa yang dipahami (mereka) adalah satu-satunya kebenaran dan akibatnya menafikan kebenaran dan keberadaan orang/kelompok lain. Islam pun kemudian dijadikan legitimasi atas tindakan 'barbar' yang dilakukan. Kasus bom di Bali misalnya, menjadi contoh penting untuk dijadikan acuan dalam menilai bagaimana hasrat kelompok tertentu berusaha menghilangkan orang lain dengan dalih agama. Bagi para pelakuknya, mati dalam melaksanakan dan setelah aksi tersebut adalah syahid, dan ganjarannya adalah syurga. Dari simpulan singkat ini dapat dilihat bahwa ada upaya menyederhanakan penafsiran sebuah dalil (ayat) sehingga seakan-akan tindakan yang dilakukan seperti pengeboman di tempat-tempat umum sah atau legal dilakukan karena ada justifikasinya dalam agama (Islam).

Tentu saja, tindakan radikal yang diawali oleh paham radikal seperti yang telah terjadi di Indonesia tidak berdiri sendiri. Konteks nasional ini tidak lepas dari konteks global. Kasus 11 September beberapa tahun lalu sangat memojokkan Islam. Hal ini pun direspons oleh kelompok-kelompok Islam di berbagai negara di dunia dengan segala bentuk aksi dan tindakan yang frontal. Hal ini juga dapat dipahami sebagai bentuk pembelaan sekaligus menunjukkan kelemahan agama. Agama cenderung pada kekerasan ketika identitasnya terancam. ${ }^{15}$ Demikian pula, kasus Palestina yang terus-menerus mendapat perlakukan tidak adil dari Israel memancing dan semakin menambah fanatisme ke-Islam-an kelompok-kelompok radikal untuk juga menyerang dan menghilangkan kelompok-kelompok yang dianggapnya memiliki hubungan dengan Israel. Inilah kemudian yang terus diproduksi dan direproduksi sehingga melahirkan simpati primordial keagamaan yang terjadi di mana-mana. Artinya, gerakan fundamentalisme Islam ternyata bukan hanya terjadi di Timur Tengah, tetapi juga di negara-negara lain yang berpenduduk Islam,

15 Hermann Haring "Mengatasi Kekerasan atas Nama Agama" dalam Wim Beuken dan Karl-Josef Kuschel (Eds), Agama sebagai Sumber Kekerasan? (Yogyakarta: Pustaka Pelajar, 2003), h. 141. 
seperti Indonesia. ${ }^{16}$ Penyerangan terhadap restauran cepat saji seperti KFC misalnya, merupakan contoh kecil betapa kebencian terhadap produk yang berbau Barat terus bertahan dan terjadi secara berulang. Sentimen antiBarat seperti ini pun dimaknai dan dimaknai oleh kelompok tertentu sebagai bentuk perjuangan melawan 'penindasan' yang dimotori oleh Barat.

Di Indonesia sendiri, radikalisme yang diwarnai oleh agama sesungguhnya bukan barang baru, khususnya terkait dengan kelompok radikal Islam. Dalam sejarah Indonesia dikenal beberapa perang misalnya Perang Padri di Sumatera Batar antara kaum ulama puritan dengan kelompok adat yang juga penganut Islam namun bukan puritan. Kaum Padri ini dikenal sebagai penganut Wahabi yang bertujuan melakukan pemurnian ajaran Islam yang diklaim telah meyimpang dari ajaran dasarnya. Hanya saja, gerakan ini diikuti oleh kekerasan sehingga terjadi pertumpahan darah di Minangkabau kala itu. Gerakan radikal Islam inilah, menurut AS Hikam, muncul kembali walaupun dalam konteks yang berbeda namun disertai dengan gagasan dan pemahaman keagamaan yang tidak jauh berbeda. ${ }^{17}$

Menyimak terjadinya reproduksi aksi radikal yang terus tumbuh dan menemukan momennya, ada satu persoalan yang juga tidak kalah pentingnya untuk disimak. Bagaimana posisi Islam itu sendiri yang notabene adalah agama rahmat? Apakah rahmat itu disebarluaskan melalui jalur kekerasan atau tindakan radikal? Pertanyaan-pertanyaan ini sangat sulit dijawab. Sebab, di internal kelompok-kelompok Islam sendiri memiliki argumen yang berbeda. Di kalangan Islam moderat misalnya, berargumen bahwa Islam semestinya dijalankan sesuai firtahnya yaitu Islam yang menjadi rahmat bagi alam yang sangat peduli dan menjunjung tinggi semangat kemanusiaan. Islam harus disebarkan dengan wajahnya yang ramah terhadap perbedaan. Islam dan Barat bukanlah perbedaan ideologis, tetapi lebih pada perbedaan geografis. Argumen ini tentu saja ditolak oleh kelompok Islam radikal karena bagi mereka justru jalur seperti

\footnotetext{
16 Afadlal, dkk, Islam dan Radikalisme di Indonesia (Jakarta: LIPI Press, 2005), h. 105. Menurut Muhammad AS Hikam, terorisme yang terjadi di Indonesia akhir-akhir ini memiliki keterkaitan ideologis, sejarah, dan politis serta merupakan bagian dari dinamika lingkungan strategis pada tataran global.

17 Muhammad AS Hikam, Peran Masyarakat Sipil Indonesia Membendung Radikalisme (Jakarta: Penerbit Kompas, 2016), h. 34,
} 
ini tidak mampu lagi membendung pengaruh Barat sehingga harus dilakukan aksi-aksi yang 'radikal'.

\section{Meminimalisir Aksi Radikal}

Kekerasan di mana saja dapat ditemukan dan terus mengalami perkembangan sesuai konteks sosial masyarakat. Tindak kekerasan mewujud dalamn beragma bentuk dan jalur. Terdapat kekerasan yang mewujud dalam bentuk tindakana atau aksi, dan sebaliknya ada dalam bentuk kekerasan verbal atau lisan. Namun tidak jarang, kedua bentuk kekerasan ini menyatu dalam sebuah peristiwa. Dalam kasus kekerasan yang mengatasnamakan agama khususnya di Indonesia, kedua bentuk kekerasan berjalan beriringan. Kasus penyerangan jamaah Ahmadiyah di Parung Bogor misalnya didahului oleh berbagai pernyataan baik di media cetak maupun elektronik mengenai penyimpangan jamaah tersebut sehingga sudah mulai terpojok secara wacana di media. Hal ini kemudian berlanjut ke perbincangan masyarakat luas yang terlebih dahulu telah memiliki prasangka yang kurang baik terhadap jamaah Ahmadiyah.

Klaim bahwa diri atau kelompoknyalah yang paling benar menjadi salah datu pemicu munculnya prasangka [buruk] kepada yang lain. Kebenaran agama (Islam) tidak cukup hanya dipahami melalui doktrinasi tanpa melihat sisi lain yang meliputi kehadiran agama dan melihat kebenaran agama lain. Sebab, jika melihat agama sebatas ini, menerima agama apa adanya, maka yang muncul adalah sikap eksklusif dan intoleransi yang justru akan semakin menjauhkan dari kehidupan yang damai. ${ }^{18}$ Adanya keyakinan seseorang terhadap Tuhan, Hari Pembalasan, Surga, dan sebagainya menunjukkan bahwa seseorang memiliki sesuatu yang lain di luar dirinya dan agamanya. Pandangan seperti tentu saja akan membawa pada sebuah analisa bahwa setiap agama memiliki aturan main sendiri yang bahkan sangat berbeda dengan agama lain dalam mengekspresikan realitas. Hanya saja, pandangan seperti ini masih menghadapi banyak kendala.

Klaim ini sedikit banyak dipengaruhi oleh cara pikir dan cara pandang seseorang/kelompok dalam memahami dalil atau teks yang cenderung melakukan penafsiran yang tidak total/komprehensif. Artinya,

\footnotetext{
18 Hafidz Hasyim, Klaim Kebenaran Agama dalam Bingkai Psikologi Agama dan Analitika Bahasa (Yogyakarta: Pustaka Pelajar-STAIN Jember Press, 2013), h. 83
} 
ada upaya penafsiran yang hanya bersifat parsial sehingga memperoleh pemahaman yang juga tidak utuh. Al-Qur'an berisi tentang akidah, syariah, dan akhlak/muamalah. Doktrin Islam tidak hanya berhenti pada rukun iman dan rukun Islam. Akan tetapi, di dalamnya juga terdapat ajaran yang mengatur bagaimana bertingkah-laku dan berelasi baik dengan sesama Islam maupun dengan non-Islam. Oleh karena itu, seluruh dimensi Islam tersebut harus dipahami secara baik dan luas ${ }^{19}$ sehingga menjadilah Muslim yang memiliki akhlak mulia sebagai manifestasi dari akidah yang murni. Antara akidah dan akhlak harus satu kesatuan, sehingga menjadi manusia yang paripurna; sempurna akidahnya dan mulia akhlaknya (insan kamil).

Salah satu terminologi yang paling sensitif dalam Islam adalah jihad. Kata jihad berasal dari kata jahada, yang berarti berusaha keras, berjuang, tenaga kerja, bersusah payah, kelelahan. ${ }^{20}$ Dari sini kemudian, beberapa sarjana khususnya sarjana Barat memahami jihad sebagai perang suci (holy war) melawan kafir $^{21}$ dan olehnya itu menurut mereka inilah asal dari radikalisme. Padahal, jihad dalam al-Qur'an memiliki beberapa makna tergantung konteksnya. Akan tetapi, interpretasi jihad yang dianggap paling sesuai adalah bagaimana menegakkan keadilan dan mengontrol keinginan (nafsu) atau godaan. ${ }^{22}$ Cara memahami ayat dibutuhkan keahlian tersendiri. Setiap ayat dalam al-Qur'an juga memiliki sebab sehingga ia diturunkan dan sangat terkait dengan konteks masyarakat kala itu. Dengan demikian, memahami ayat dari teks atau tulisannya saja tidaklah cukup, ia harus dipahami dari aspek lain yaitu konteks masyarakat yang menyebabkan sebuah ayat turun, termasuk ayat mengenai jihad.

${ }^{19}$ Hasse J, Reproduksi Kekerasan: studi Relasi antara Negara, Agama, dan Anarkisme", Jurnal At Tafkir: Media Pendidikan, Hukum, dan Sosial Keagamaan Vol IV, Nomor 2 Desember (Langsa NAD: STAIN Zawiyah Cot Kala, 2011), h. 3.

${ }^{20}$ Paul Ernest Wehr \& Heidi Burgess, Justice without Violance (Boulder and London: Lynne Rienner Publishers, 1994), h. 142.

${ }^{21}$ David Cook, Understanding Jihad (California: University of California Press, 2005).

${ }^{22}$ Kamaruzzaman Bustaman-Ahmad, From Islamic Revivalism ti Islamic Radicalism in Southeast Asia:a Study of Jama'ah Tabligh in Malaysia and Indonesia (UK: Cambridge Scholars Publishing, 2015), h. 7 
Beberapa ayat dalam al-Qur'an dikategorikan sebagai ayat inklusif, toleran, dan penuh semangat kerukunan. Bahkan, ayat yang tegas menunjuk kepada kelompok atau kaum musyrikin pun memiliki standar yang sama menyangkut 'keputusan' Tuhan. Pada Surah Al Baqarah ayat 62 misalnya dikatakan;

"Sesungguhnya orang-orang mukmin, orang-orang Yahudi, orang-orang Nasrani dan orang-orang shabi'in, siapa saja di antara mereka beriman kepada Allah, hari kemudian, dan beraman saleh, mereka akan menerima pahala dari Tuhan, tidak ada kekhawatiran terhadap mereka, dan tidak pula bersedih hati" (QS. Al Baqarah: 62).

Dari ayat tersebut terlihat bahwa persoalan keimanan dan perbuatanlah yang menentukan 'nasib' seseorang penganut agama, bukan agama yang dianutnya sehingga peluang untuk menemukan kebaikan di agama-agama lain tentu saja ada. Hanya saja, pemikiran seperti ini ditolak khususnya oleh kelompok Islam garis keras yang sangat aktif dan masif melakukan berbagai aksi.

Radikalisme agama disebabkan oleh adanya kehendak totalitalitasi manusia dalam kerangka pemikiran. Mulai dari kodifikasi tafsir, pembentukan identitas hingga pada legitimasi moral, pada dasarnya merupakan sikap totaliter. Menstigmatisasi orang lain adalah cara untuk memasukkan orang lain dalam "keseluruhan" hingga tidak lagi tampak keunikan masing-masing. Hanah Arendt, filsuf perempuan yang pernah mengalami represi karena ke-Yahudi-annya, mengingatkan, "kita tergoda untuk menodai usaha yang telah kita perjuangkan melawan totalitarianisme dengan suatu fanatisme. Padahal, fanatisme adalah musuh besar kebebasan”. Singkatnya, ada sikap yang selalu dipaksakan termasuk memaksakan kehendak dan memaksa orang/kelompok lain mengikuti diri/kelompoknya dengan berbagai cara termasuk menggunakan simbol agama sebagai alat justifikasi tindakannya. Tidak peduli apakah itu teror atau apa, yang terpenting adalah bagaimana orang lain mengikuti kehendak, jika tidaka maka kekerasan pun menjadi pilihannya.

Seturut dengan itu, Franz Magnis-Suseno mengatakan bahwa, kita harus mewaspadai adanya tendensi-tendensi totaliter, atau potensi menjadi totaliter. Tendensi totaliter ini berupa (1) legitimasi gampang atas pelanggaran hak asasi manusia atas tujuan ideologi; (2) monopoli informasi dengan alasa pemerintah lebih tahu apa yang harus dielakkan masyarakat; (3) pembatasan pengorganisasian masyarakat pada organisasi-organisasi yang disiapkan pemerintah; penggunaan cara-cara di 
luar hukum untuk mengancam tidak hanya dianggap sebagai penjahahat, tetapi juga seluruh masyarakat, agar takut dan tidak berani mempertanyakan kebijakan pemerintah. ${ }^{23}$ Singkatnya, ada upaya pembungkaman yang dilakukan secara terencana dan tertata dengan baik sehingga masyarakat patuh dan tidak memiliki pilihan lain untuk melakukan koreksi. Keterbukaan seakan tidak berlaku sehingga apa pun yang dilakukan di luar sistem yang berkuasa merupakan bentuk perlawan dan harus ditiadakan.

Cara lain untuk melakukan kritik terhadap fundamentalisme adalah dengan hermeneutika, artinya melakukan penafsiran terhadap teks atau ayat menggunakan metode yang tidak hanya terpaku pada teks. Selain teks, tafsir menggunakan cara ini juga sangat memperhatikan konteks kemudian kontekstualisasi. Cara ini diletakkan sebagai kritik atas ideologi pada agama yang dibangun berdasarkan prasangka dan ilusi agama. Sebagai contohnya, dilakukannya penafsiran tafsir yang lebih inklusif terhadap teks suci (ayat). Upaya ini akan memberikan counter terhadap dominasi tafsir kelompok tertentu. Sebab, bagaimana pun "iman selalu mencari pendasaran rasional" (fides quarens intelektum), bukan didasarkan pada sangkaan dan kefanatikan. Dari cara ini maka terbukalah "kedok" tafsir yang dangkal yang selalu menyembuyikan struktur kuasa dan dominasi kelompok tertentu. Bahkan lebih dari itu, hermeneutika akan membongkar kerangka ilutif, motivasi, tujuan dan kepentingan kelompok tertentu atas komodifikasi tafsirnya itu sendiri.

Aktor penting yang memiliki otoritas melakukan penafsiran terhadap seperti ulama sebaiknya diberikan ruang yang cukup luas untuk menggeluti tugas berat ini. Selama ini, tafsir cenderung dilakukan oleh orang atau kelompok yang secara keilmuan tidak 'pantas' dan tidak cukup syarat melakukan hal tersebut. Sebuah ayat tidak hanya ditafsirkan berdasar pada terjemahannya, tetapi memiliki banyak aspek yang harus dikaji seperti aspek kebahasaan dan struktur kalimat yang melingkupi teks atau ayat tersebut. Dalam keseharian umat Islam selama ini, disuguhi berbagai ceramah agama yang lebih cenderung menjauh dari esensi dakwah Islam itu sendiri. Di berbagai media, khususnya elektronik, pada penceramah lebih mengejar popularitas sehingga yang disampaikan pun hanya yang membuat orang tertawa dan melupakan pesan pokok yang disampaikan.

${ }^{23}$ Rieke Diah Pitaloka, Banalitas Kekerasan: Telaah Pemikiran Hannah Arendt tentang Kekerasan Negara (Depok: Koekoesan, 2010), h. 3-4. 
Selain tafsir yang komprehensif kontekstual, metode lain yang dapat digunakan adalah melakukan berbagai upaya dalam rangka menangkal radikalisme tumbuh dan berkembang di Indonesia. Negara telah memiliki instrumen teknis dalam menjalankan berbagai program seperti ini. Adanya lembaga khusus yang dibentuk menunjukkan tingginya komitmen negara melindungi dan menjauhkan warganya dari ancaman radikalisme dan tentu saja terorisme. Negara semestinya tidak sekadar hadir di tengah kegelisahan bahkan ketakukan warganya. Yang terpenting lagi, negara hadir bukan justru menaklukkan, tetapi negara hadir dalam rangka memberikan rasa aman dan menjamin keberlangsungan warganya. BNPT atau Badan Nasional Penanggulangan Terorisme, di tengah berbagai kritik yang dialamatkan ke lembaga ini, sedikit banyak menunjukkan hadirnya negara dalam upaya melindungi warganya di tengah ancaman radikalisme dan terorisme yang selama ini. Berbagai program yang dimaksudkan memberikan pengenalan mengenai terororisme dan radikalisme serta dampaknya terus dilakukan kepada masyarakat luas dengan harapan akan diperoleh pengetahuan dan pemahaman yang baik mengenai terorisme dan radikalisme.

\section{E. Kesimpulan}

Radikalisme di Indonesia memiliki potensi yang sangat terbuka untuk terus berkembang. Kemunculan paham ini juga tidak lepas konteks dan realitas umat Islam yang mayoritas di negeri ini. Sebagai mayoritas, selalu muncul perasaan ingin menunjukkan dominasi di satu sisi, dan tentu saja diikuti oleh upaya untuk melanggengkan dominasi tersebut di sisi lain. Hanya saja, pilihan cara atau metode mencapai tujuan, dominasi dan mempertahankannya dilakukan dengan cara-cara kekerasan. Tulisan ini menyimpulkan tiga hal. Pertama, sesunguhnya agama manapun khususnya Islam tidak mengajarkan umatnya melakukan tindakan kekerasan untuk mencapai setiap hasratnya. Hanya saja, terdapat konsep yang dipahami oleh sebagian umat yang mengarah pada seruan untuk melakukan hal-hal yang radikal, misalnya konsep tentang jihad. Terjadinya aksi atau tindakan kekerasan yang mengatasnamakan agama khususnya Islam tidak lepas dari kondisi umat Islam dan dunia Islam sendiri saat ini yang mengalami berbagai persolan pelik di berbagai belahan dunia dan tidak mendapat jalan pemecahan sehingga tindakantindakan intimidatif masih dialami. 
Kedua, kemunculan radikalisme yang diikuti oleh tindakan radikal menunjukkan adanya perasaan yang senantiasa terhubung antara umat Islam di suatu tempat dengan umat Islam di tempat-tempat lain yang mengalami perlakuan diskriminatif. Berbagai aksi seperti penyerangan tempat ibadah hingga bom yang menyasar keramaian merupakan tindakan yang tidak berdiri sendiri. Ada kecenderungan bahwa apa yang terjadi terhadap umat Islam di belahan dunia lain, akan direspons oleh umat Islam di tempat lain pula. Demikian pula, adanya pemahaman yang sempit terhadap doktrin agama memberikan peluang yang cukup terbuka kepada 'oknum' penganut agama untuk melakukan tindakan yang jauh dari esensi agamanya sendiri. Aksi radikal pun menjadi pilihan merespons berbagai kondisi umat.

Ketiga, untuk berupaya mereduksi berbagai pemahaman yang mengarah pada radikalisme, dibutuhkan pendekatan atau tafsir yang komprehensif untuk memahami doktrin agama. Salah satu model atau metode yang dapat dilakukan adalah melalui hermeneutik. Dengan tafsir ini, pemahaman terhadap teks agama (ayat) dilakukan secara luas, yang tidak hanya terpaku pada teks yang dikaji tetapi yang juga memperhatikan dan menyimak secara mendalam konteks sosial dari teks tersebut. Hermeneuti sangat memungkinkan akan diperoleh pemahaman yang mendalam terhadap teks sehingga tidak dengan mudah berhenti pada pemahaman yang dangkal dan parsial. Pemahaman terhadap teks atau ayat pun semakin luas sehingga Islam pun mewujud sebagai agama yang betulbetul menjadi rahmat bukan hanya bagi pemeluknya, tetapi juga bagi alam berserta seluruh isinya. Selain itu, dibutuhkan upaya ril dalam rangka melakukan proteksi dini terhadap berbagai tindakan yang merugikan banyak pihak. Negara dalam hal ini selalu berada di posisi paling depan. Negara tidak sekadar hadir, tetapi kehadirannya membawa dampak berupa penciptaan rasa aman dan terjaminnya keberlangsungan hajat orang banyak.

\section{DAFTAR PUSTAKA}

Afadlal, dkk, 2005, Islam dan Radikalisme di Indonesia. Jakarta: LIPI Press.

AS Hikam, Muhammad, 2016, Peran Masyarakat Sipil Indonesia Membendung Radikalisme. Jakarta: Penerbit Kompas. 
Bustaman-Ahmad, Kamaruzzaman, 2015. From Islamic Revivalism ti Islamic Radicalism in Southeast Asia: a Study of Jama'ah Tabligh in Malaysia and Indonesia. UK: Cambridge Scholars Publishing.

Cook, David, 2005, Understanding Jihad. California: University of California Press.

Haring, Hermann, 2003, "Mengatasi Kekerasan atas Nama Agama" dalam Wim Beuken dan Karl-Josef Kuschel (Eds), Agama sebagai Sumber Kekerasan? Yogyakarta: Pustaka Pelajar.

Haryatmoko, 2003, Etika Politik dan Kekuasaan. Jakarta: Kompas.

Hasse J, 2011, "Reproduksi Kekerasan: studi Relasi antara Negara, Agama, dan Anarkisme", Jurnal At Tafkir: Media Pendidikan, Hukum, dan Sosial Keagamaan Vol IV, Nomor 2 Desember. Langsa NAD: STAIN Zawiyah Cot Kala, hal. 3.

Hasse J, 2014, Konformitas Islam dan Adat: Potret Fanatisme Keagamaan di Kalangan Muslim Bugis, Jurnal Jabal Hikmah, Vol. 3 No. 2, 199.

Hasyim, Hafidz, 2013, Klaim Kebenaran Agama dalam Bingkai Psikologi Agama \& Analitika Bahasa. Klaim Kebenaran Agama dalam Bingkai Psikologi Agama \& Analitika Bahasa. Yogyakarta: Pustaka Pelajar-STAIN Jember Press.

Heclo, Hug, 2001, "Religion and Public Policy: An Introduction", Journal of Policy History, Vol. 13. Issue 1.

Pals, Daniel L, 2012, Seven Theories of Religion. Terj. Inyiak Ridwan Muzir. Yogyakarta: IRCiSod.

Pitaloka, Rieke Diah, 2010, Banalitas Kekerasan: Telaah Pemikiran Hannah Arendt tentang Kekerasan Negara. Depok: Koekoesan.

Qodir, Zuly, 2014, Radikalisme Agama di Indonesia. Yogyakarta: Pustaka Pelajar.

Sirry, Mun'in A, 2003, Membendung Militansi Agama: Iman dan Politik dalam Masyarakat Modern. Jakarta: Penerbit Erlangga.

Sukardi, Imam dkk, 2003, Pilar Islam bagi Pluralisme Modern. Solo: Tiga Serangkai.

Takbir, Muhammad, 2015, Etika Religious Emmanuel Levinas dalam Perspektif Filsafat Agama dan Relevansinya dengan Pluralitas di Indonesia, "Tesis". Yogyakarta: Program Pascasarjana Ilmu Filsafat UGM.

Wehr, Paul Ernest \& Heidi Burgess, 1994, Justice without Violence. Boulder and London: Lynne Rienner Publishers. 